\title{
An international study of the exposure of children to traffic
}

Ian Roberts, John Carlin, Catherine Bennett, Erik Bergstrom, Bernard Guyer, Terry Nolan, Robyn Norton, I Barry Pless, Ravi Rao, Mark Stevenson`

\begin{abstract}
Objectives-To examine the extent of international differences in children's exposure to traffic as pedestrians or bicyclists.
\end{abstract}

Design-Children's travel patterns were surveyed using a parent-child administered questionnaire. Children were sampled via primary schools, using a probability cluster sampling design.

Health, University of London, London, UK I Roberts

Clinical Epidemiology and Biostatistics Unit, Royal

Children's Hospital, University of

Melbourne,

Melbourne, Australia

$\mathrm{J}$ Carlin

C Bennett

$T$ Nolan

Department of Paediatrics,

University of Umea,

Umeå, Sweden

E Bergstrom

Department of Maternal and Child Health, School of

Hygiene and Public

Health, Johns

Hopkins University,

Balitmore, USA

B Guyer

R Rao

Injury Prevention

Research Centre,

Department of

Community Health,

University of

Auckland, Auckland,

New Zealand

R Norton

Department of

Community

Paediatric Research,

Montreal Children's

Hospital, McGill

University,

Montreal, Canada

B Pless

Department of Epidemiology and Biostatistics, School of Public Health, Curtin University of Technology, Perth, Australia

M Stevenson

Correspondence to: Ian Roberts, Department of Epidemiology, Institute of Child Health, 30 Guilford Street, London WC1N 1EH, UK.
Setting-Six cities in five countries: Melbourne and Perth (Australia), Montreal (Canada), Auckland (New Zealand), Umeå (Sweden), and Baltimore (USA).

\section{Subjects-Children aged 6 and 9 years.}

Main outcome measures-Modes of travel on the school-home journey, total daily time spent walking, and the average daily number of roads crossed.

Main findings-Responses were obtained from the parents of 13423 children. There are distinct patterns of children's travel in the six cities studied. Children's travel in the three Australasian cities, Melbourne, Perth and Auckland, is characterised by high car use, low levels of bicycling, and a steep decline in walking with increasing car ownership. In these cities, over a third of the children sampled spent less than five minutes walking per day. In Montreal, walking and public transport were the most common modes of travel. In Umeå, walking and bicycling predominated, with very low use of motorised transport. In comparison with children in the Australasian and North American cities, children in Umeå spend more time walking, with $87 \%$ of children walking for more than five minutes per day.

Conclusions-There are large international differences in the extent to which children walk and cycle. These findings would suggest that differences in 'exposure to risk' may be an important contributor to international differences in pedestrian injury rates. There are also substantial differences in pedestrian exposure to risk by levels of car ownershipdifferences that may explain socioeconomic differentials in pedestrian injury rates.

(Injury Prevention 1997; 3: 89-93)

Keywords: pedestrian; exposure; bicyclist; traffic.
The increase in the use of motorised transport during the second half of the twentieth century has had important implications for child health. In the heavily motorised countries, pedestrian-motor vehicle collisions are a leading cause of death in childhood, and an important cause of acquired disability. ${ }^{2}$ In addition, the use of car travel for journeys that would previously have been made on foot has provoked concerns about declining levels of physical activity in childhood, and the effect this might have on health in later life. ${ }^{34} \mathrm{~A}$ deeper understanding of both these issues requires information about travel patterns in childhood.

The concept of 'exposure to risk' is central to understanding the epidemiology of childhood traffic injuries. Children who are driven to school are exposed to the risk of vehicle occupant injury but are not exposed to the risk of pedestrian injury on that particular journey. For child pedestrian injury, an understanding of how pedestrian exposure to risk varies between and within populations may answer some of the most important etiologic questions: why injury rates vary between countries and why some population subgroups have higher injury rates than others.

There are striking international differences in child pedestrian death rates. By comparison with Sweden in 1987, the mortality rate in New Zealand was 2.1 times higher, and in the USA 1.9 times higher. ${ }^{5}$ The low death rate in Sweden has been the subject of considerable speculation. It has been suggested that it is the result of urban planning initiatives, taken in the early $1960 \mathrm{~s}$, that increased the safety of children as pedestrians. ${ }^{6}$ An alternative explanation is that Swedish children walk less, in which case the low injury rate may represent a trade-off between injury risk and the benefits of physical activity. To examine the extent of international differences in child pedestrian exposure to risk, we surveyed the travel patterns of young school aged children in Australia, Canada, New Zealand, Sweden, and the USA.

\section{Methods}

Children from six cities in five countries were surveyed: Melbourne and Perth (Australia),

*Editors note: readers will note that this paper includes several members of the editorial board among its authors. To avoid my cors of the edictial handled by an interst, the entire reving handled by an associate editor - as they say in the judiciary, 
Montreal (Canada), Auckland (New Zealand), Umeå (Sweden), and Baltimore (USA). Study cities were a convenience sample, chosen because they provided a broad geographical coverage and because people with the interest and expertise necessary to conduct the present study were located in them. Subjects were selected using a probability cluster design, except in Umeå, where all children in the desired age range were approached. For the two stage sampling, the sampling frames for the primary sampling units were lists of all primary schools in the sampled cities. Schools were selected with probability proportional to total enrolment in the age groups of interest. Two age groups were selected: 6 year olds and 9 years olds because pedestrian injury rates are highest between these ages. In Melbourne, a single class at each age level was randomly selected, while in the other centres all children in the relevant grades of the selected schools were invited to participate. To account for seasonal differences in children's travel patterns, all surveys were conducted in the spring: September to November 1994 for the southern hemisphere cities, and May to June 1995 for the northern hemisphere cities.

Children's travel patterns were determined using a questionnaire that was distributed in the classroom, to be completed at home with their parents. This questionnaire included questions about each part of the day (before school, going to school, returning from school, and after school) to determine the mode of travel used, the number and type of streets crossed on foot, and the total time spent walking. Identical questions were asked at each site. We also asked about home and car ownership as indicators of socioeconomic position. Children were asked to complete the questionnaire with their parents in the evening, by systematically reviewing their travel patterns for that day. Before the main survey, the questionnaire was pilot tested in Melbourne, Perth, Auckland, and Seattle. Questionnaires were issued on a second occasion if the first was not returned. Response rates were calculated as the proportion of all first issue questionnaires that were completed and returned.

The statistical software package Stata (Stata Corporation, College Station, Texas) was used to analyse the data. To ensure that intraschool correlations were adequately controlled for, and to compensate for differences in response rates between schools, analyses were based on cluster specific means. ${ }^{7}$ Total population means were estimated as the means of the cluster means. To account for the varying numbers in subcategories (age, sex, and other covariates of interest), mean values within population subcategories were estimated using the means of the mean values obtained within each school, weighted proportionately to the sample number and inverse proportionately to the cluster size.

Ethics committee approval was obtained at each site.

\section{Results}

A total of 13423 completed questionnaires were returned. The number of children surveyed and the response rates for the individual sites are shown in table 1 . There were large differences in travel patterns between the study cities. For example, for the journey to schook. (table 2), car travel was the predominant mode of travel in Melbourne (61\%), Perth $(62 \%) \stackrel{\text { ? }}{+}$ and Auckland (55\%), while walking was the predominant mode of travel in Montrea (48\%), Umeå (41\%), and Baltimore (55\%) The use of public transport ranged from $36 \%$ in Montreal to $1 \%$ in Perth. The proportion of children who bicycled to school ranged from $\vec{p}$ $31 \%$ in Umeå to $0 \%$ in Baltimore. Apart from Baltimore, where there was no bicycling, theren was an increase in bicycle use with age, anफ़् more boys than girls bicycled to school. In alf six cities, there was a steep decline in the exten 60 to which children walk to school with increasing car ownership.

Details of the mode of travel from schoo are shown in table 3 . In every city, a smalles proportion of children were driven home from school than were driven to school $\overrightarrow{0}$ and there was a small increase in the proportion who walked. Car travel predominated in Melbourne and Perth, but mores children walked than were driven in Auck land. Walking was the most common modê of travel from school in Montreal, Umeå, an® Baltimore. Patterns of bicycling and public $\overrightarrow{5}$ transport use were similar to that for the journey to school.

Table 4 gives the mean daily number of streets crossed on foot by age, sex, and cas ownership. The mean number of streets= crossed on foot ranged from 5.1 streets pee day in Montreal to 2.3 in Perth. The number of streets crossed by boys was similar to that for girls, but there was an increase in street crossings with increasing age. The number of streets crossed was also strongly related to cap. ownership, with children from families with out a car crossing the greatest number of streets.

The proportions of children who walk for less than five and less than 15 minutes per day. are shown in table 5 . In Perth, $52 \%$ of children spent less than five minutes walking and $76 \%$ spent less than 15 minutes. In contrast in Umeå, $13 \%$ of children walked for less than five minutes and $45 \%$ walked for less than $1 \%$ minutes. There was an increase in the propor tions of children who walked for less than five and 15 minutes per day with increasing car ownership.

In Melbourne and Montreal, data wered available on the response rate for each indivi $\frac{\text { के }}{\circ}$

\begin{tabular}{lcccc} 
& & & \\
Table 1 & Numbers sampled and response rates & Oे \\
\hline Site & Schools & Children & Response rate & (\%) \\
& & & & 0 \\
Melbourne & 72 & 3198 & 82 \\
Perth & 48 & 2781 & 65 \\
Auckland & 40 & 2871 & 85 \\
Montreal & 43 & 2501 & 61 \\
Baltimore & 24 & 861 & 29 \\
Umeå & 43 & 1211 & 46 \\
\hline
\end{tabular}


Table 2 Mode of travel to school (values are percentages using particular mode)

\begin{tabular}{|c|c|c|c|c|c|c|c|c|}
\hline \multirow[b]{2}{*}{ Site } & \multirow[b]{2}{*}{ Total } & \multicolumn{2}{|l|}{ Boys } & \multicolumn{2}{|l|}{ Girls } & \multicolumn{3}{|c|}{ Car ownership } \\
\hline & & 6 years & 9 years & 6 years & 9 years & No car & One car & Two cars \\
\hline $\begin{array}{l}\text { Melbourne } \\
\text { Walked } \\
\text { Car } \\
\text { Public transport } \\
\text { Bicycle }\end{array}$ & $\begin{array}{r}35 \\
61 \\
2 \\
3\end{array}$ & $\begin{array}{r}35 \\
63 \\
1 \\
1\end{array}$ & $\begin{array}{r}36 \\
56 \\
2 \\
6\end{array}$ & $\begin{array}{r}30 \\
68 \\
1 \\
1\end{array}$ & $\begin{array}{r}38 \\
57 \\
3 \\
3\end{array}$ & $\begin{array}{r}81 \\
11 \\
6 \\
2\end{array}$ & $\begin{array}{r}42 \\
52 \\
2 \\
4\end{array}$ & $\begin{array}{r}27 \\
69 \\
1 \\
3\end{array}$ \\
\hline $\begin{array}{l}\text { Perth } \\
\text { Walked } \\
\text { Car } \\
\text { Public transport } \\
\text { Bicycle }\end{array}$ & $\begin{array}{c}31 \\
62 \\
1 \\
6\end{array}$ & $\begin{array}{r}31 \\
66 \\
1 \\
3\end{array}$ & $\begin{array}{r}30 \\
57 \\
1 \\
13\end{array}$ & $\begin{array}{r}29 \\
69 \\
1 \\
2\end{array}$ & $\begin{array}{r}35 \\
58 \\
2 \\
6\end{array}$ & $\begin{array}{r}59 \\
20 \\
7 \\
14\end{array}$ & $\begin{array}{r}37 \\
55 \\
1 \\
6\end{array}$ & $\begin{array}{r}26 \\
68 \\
1 \\
5\end{array}$ \\
\hline $\begin{array}{l}\text { Auckland } \\
\text { Walked } \\
\text { Car } \\
\text { Public transport } \\
\text { Bicycle }\end{array}$ & $\begin{array}{r}40 \\
55 \\
5 \\
1\end{array}$ & $\begin{array}{r}37 \\
58 \\
4 \\
1\end{array}$ & $\begin{array}{r}41 \\
52 \\
5 \\
2\end{array}$ & $\begin{array}{r}37 \\
56 \\
7 \\
0\end{array}$ & $\begin{array}{r}43 \\
52 \\
5 \\
1\end{array}$ & $\begin{array}{r}80 \\
16 \\
3 \\
1\end{array}$ & $\begin{array}{r}50 \\
45 \\
4 \\
1\end{array}$ & $\begin{array}{r}28 \\
65 \\
7 \\
1\end{array}$ \\
\hline $\begin{array}{l}\text { Montreal } \\
\text { Walked } \\
\text { Car } \\
\text { Public transport } \\
\text { Bicycle }\end{array}$ & $\begin{array}{l}48 \\
14 \\
36 \\
2\end{array}$ & $\begin{array}{l}46 \\
16 \\
37 \\
1\end{array}$ & $\begin{array}{l}46 \\
14 \\
35 \\
6\end{array}$ & $\begin{array}{l}53 \\
14 \\
33 \\
0\end{array}$ & $\begin{array}{l}46 \\
14 \\
39 \\
2\end{array}$ & $\begin{array}{l}60 \\
2 \\
35 \\
2\end{array}$ & $\begin{array}{l}51 \\
13 \\
35 \\
2\end{array}$ & $\begin{array}{l}32 \\
27 \\
40 \\
2\end{array}$ \\
\hline $\begin{array}{l}\text { Baltimore } \\
\text { Walked } \\
\text { Car } \\
\text { Public transport } \\
\text { Bicycle }\end{array}$ & $\begin{array}{r}55 \\
38 \\
6 \\
0\end{array}$ & $\begin{array}{r}47 \\
45 \\
8 \\
0\end{array}$ & $\begin{array}{r}62 \\
35 \\
3 \\
0\end{array}$ & $\begin{array}{r}53 \\
40 \\
8 \\
0\end{array}$ & $\begin{array}{r}61 \\
34 \\
5 \\
0\end{array}$ & $\begin{array}{r}88 \\
6 \\
6 \\
0\end{array}$ & $\begin{array}{r}48 \\
44 \\
8 \\
0\end{array}$ & $\begin{array}{r}39 \\
59 \\
3 \\
0\end{array}$ \\
\hline $\begin{array}{l}\text { Umeå } \\
\text { Walked } \\
\text { Car } \\
\text { Public transport } \\
\text { Bicycle }\end{array}$ & $\begin{array}{l}41 \\
18 \\
10 \\
31\end{array}$ & $\begin{array}{l}35 \\
30 \\
11 \\
24\end{array}$ & $\begin{array}{r}46 \\
5 \\
10 \\
39\end{array}$ & $\begin{array}{l}40 \\
27 \\
10 \\
23\end{array}$ & $\begin{array}{r}43 \\
5 \\
10 \\
41\end{array}$ & $\begin{array}{r}67 \\
2 \\
4 \\
27\end{array}$ & $\begin{array}{r}44 \\
17 \\
5 \\
35\end{array}$ & $\begin{array}{l}30 \\
23 \\
24 \\
24\end{array}$ \\
\hline
\end{tabular}

Table 3 Mode of travel from school (values are percentages using particular mode)

\begin{tabular}{|c|c|c|c|c|c|c|c|c|}
\hline \multirow[b]{2}{*}{ Site } & \multirow[b]{2}{*}{ Total } & \multicolumn{2}{|l|}{ Boys } & \multicolumn{2}{|l|}{ Girls } & \multicolumn{3}{|c|}{ Car ownership } \\
\hline & & 6 years & 9 years & 6 years & 9 years & No car & One car & Two cars \\
\hline 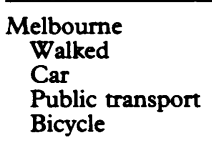 & $\begin{array}{r}40 \\
55 \\
2 \\
3\end{array}$ & $\begin{array}{r}40 \\
58 \\
2 \\
1\end{array}$ & $\begin{array}{r}43 \\
49 \\
2 \\
6\end{array}$ & $\begin{array}{r}34 \\
63 \\
2 \\
3\end{array}$ & $\begin{array}{r}43 \\
52 \\
2 \\
3\end{array}$ & $\begin{array}{r}82 \\
9 \\
8 \\
1\end{array}$ & $\begin{array}{r}46 \\
47 \\
2 \\
4\end{array}$ & $\begin{array}{r}34 \\
62 \\
2 \\
3\end{array}$ \\
\hline $\begin{array}{l}\text { Perth } \\
\text { Walked } \\
\text { Car } \\
\text { Public transport } \\
\text { Bicycle }\end{array}$ & $\begin{array}{r}33 \\
59 \\
2 \\
6\end{array}$ & $\begin{array}{r}32 \\
65 \\
1 \\
3\end{array}$ & $\begin{array}{r}33 \\
53 \\
2 \\
12\end{array}$ & $\begin{array}{r}31 \\
66 \\
2 \\
2\end{array}$ & $\begin{array}{r}38 \\
53 \\
3 \\
6\end{array}$ & $\begin{array}{r}59 \\
23 \\
7 \\
11\end{array}$ & $\begin{array}{r}40 \\
52 \\
2 \\
6\end{array}$ & $\begin{array}{r}29 \\
64 \\
2 \\
5\end{array}$ \\
\hline $\begin{array}{l}\text { Auckland } \\
\text { Walked } \\
\text { Car } \\
\text { Public transport } \\
\text { Bicycle }\end{array}$ & $\begin{array}{r}49 \\
44 \\
6 \\
1\end{array}$ & $\begin{array}{r}44 \\
50 \\
5 \\
1\end{array}$ & $\begin{array}{r}53 \\
39 \\
6 \\
2\end{array}$ & $\begin{array}{r}46 \\
47 \\
6 \\
0\end{array}$ & $\begin{array}{r}55 \\
38 \\
6 \\
0\end{array}$ & $\begin{array}{r}84 \\
12 \\
3 \\
2\end{array}$ & $\begin{array}{r}60 \\
35 \\
4 \\
1\end{array}$ & $\begin{array}{r}40 \\
53 \\
7 \\
1\end{array}$ \\
\hline $\begin{array}{l}\text { Montreal } \\
\text { Walked } \\
\text { Car } \\
\text { Public transport } \\
\text { Bicycle }\end{array}$ & $\begin{array}{r}50 \\
13 \\
36 \\
2\end{array}$ & $\begin{array}{r}47 \\
14 \\
38 \\
1\end{array}$ & $\begin{array}{r}50 \\
10 \\
35 \\
5\end{array}$ & $\begin{array}{r}54 \\
14 \\
32 \\
0\end{array}$ & $\begin{array}{r}48 \\
14 \\
37 \\
2\end{array}$ & $\begin{array}{r}62 \\
2 \\
35 \\
1\end{array}$ & $\begin{array}{r}53 \\
11 \\
34 \\
2\end{array}$ & $\begin{array}{r}34 \\
25 \\
39 \\
2\end{array}$ \\
\hline $\begin{array}{l}\text { Baltimore } \\
\text { Waalked } \\
\text { Car } \\
\text { Public transport } \\
\text { Bicycle }\end{array}$ & $\begin{array}{r}69 \\
25 \\
6 \\
0\end{array}$ & $\begin{array}{r}63 \\
30 \\
7 \\
0\end{array}$ & $\begin{array}{r}76 \\
21 \\
3 \\
0\end{array}$ & $\begin{array}{r}68 \\
24 \\
8 \\
0\end{array}$ & $\begin{array}{r}70 \\
25 \\
5 \\
0\end{array}$ & $\begin{array}{r}90 \\
3 \\
6 \\
0\end{array}$ & $\begin{array}{r}69 \\
24 \\
7 \\
0\end{array}$ & $\begin{array}{r}52 \\
44 \\
5 \\
0\end{array}$ \\
\hline $\begin{array}{l}\text { Umea } \\
\text { Walked } \\
\text { Car } \\
\text { Public transport } \\
\text { Bicycle }\end{array}$ & $\begin{array}{l}43 \\
15 \\
10 \\
32\end{array}$ & $\begin{array}{l}37 \\
26 \\
12 \\
25\end{array}$ & $\begin{array}{r}46 \\
4 \\
9 \\
41\end{array}$ & $\begin{array}{r}45 \\
22 \\
9 \\
24\end{array}$ & $\begin{array}{r}45 \\
4 \\
10 \\
41\end{array}$ & $\begin{array}{r}67 \\
4 \\
4 \\
25\end{array}$ & $\begin{array}{r}46 \\
12 \\
5 \\
36\end{array}$ & $\begin{array}{l}32 \\
22 \\
21 \\
26\end{array}$ \\
\hline
\end{tabular}

Table 4 Average (daily) number of streets crossed by foot

\begin{tabular}{|c|c|c|c|c|c|c|c|c|}
\hline \multirow[b]{2}{*}{ Site } & \multirow[b]{2}{*}{ Total } & \multicolumn{2}{|l|}{ Boys } & \multicolumn{2}{|l|}{ Girls } & \multicolumn{3}{|c|}{ Car ownership } \\
\hline & & 6 years & 9 years & 6 years & 9 years & No car & One car & Two cars \\
\hline $\begin{array}{l}\text { Melbourne } \\
\text { Perth } \\
\text { Auckland } \\
\text { Montreal } \\
\text { Baltimore } \\
\text { Umea }\end{array}$ & $\begin{array}{l}3.6 \\
2.3 \\
2.5 \\
5.1 \\
3.9 \\
4.1\end{array}$ & $\begin{array}{l}3.4 \\
2.2 \\
2.4 \\
4.3 \\
4.0 \\
3.7\end{array}$ & $\begin{array}{l}3.9 \\
2.5 \\
2.8 \\
6.0 \\
4.5 \\
5.0\end{array}$ & $\begin{array}{l}2.8 \\
1.9 \\
2.1 \\
5.1 \\
3.3 \\
3.3\end{array}$ & $\begin{array}{l}3.9 \\
2.7 \\
2.9 \\
4.9 \\
4.2 \\
4.5\end{array}$ & $\begin{array}{l}8.8 \\
4.8 \\
5.3 \\
5.9 \\
5.7 \\
4.5\end{array}$ & $\begin{array}{l}4.3 \\
2.8 \\
3.0 \\
5.4 \\
3.8 \\
4.3\end{array}$ & $\begin{array}{l}2.8 \\
1.9 \\
2.0 \\
3.9 \\
2.8 \\
3.7\end{array}$ \\
\hline
\end{tabular}


Table 5 Percentages of children who spend less than five and less than 15 minutes walking per day (before school, to school, from school, and after school)

\begin{tabular}{|c|c|c|c|c|c|c|c|c|}
\hline \multirow[b]{2}{*}{ Site (time in mins) } & \multirow[b]{2}{*}{ Total } & \multicolumn{2}{|l|}{ Boys } & \multicolumn{2}{|l|}{ Girls } & \multicolumn{3}{|c|}{ Car ownership } \\
\hline & & 6 years & 9 years & 6 years & 9 years & No car & One car & Two cars \\
\hline \multicolumn{9}{|l|}{ Melbourne } \\
\hline $\begin{array}{l}<5 \\
<15\end{array}$ & $\begin{array}{l}44 \\
72\end{array}$ & $\begin{array}{l}45 \\
74\end{array}$ & $\begin{array}{l}41 \\
68\end{array}$ & $\begin{array}{l}50 \\
78\end{array}$ & $\begin{array}{l}40 \\
70\end{array}$ & $\begin{array}{l}11 \\
34\end{array}$ & $\begin{array}{l}39 \\
67\end{array}$ & $\begin{array}{l}49 \\
77\end{array}$ \\
\hline \multicolumn{9}{|l|}{ Perth } \\
\hline $\begin{array}{l}<5 \\
<15\end{array}$ & $\begin{array}{l}52 \\
76\end{array}$ & $\begin{array}{l}54 \\
76\end{array}$ & $\begin{array}{l}49 \\
75\end{array}$ & $\begin{array}{l}57 \\
79\end{array}$ & $\begin{array}{l}48 \\
75\end{array}$ & $\begin{array}{l}44 \\
58\end{array}$ & $\begin{array}{l}46 \\
71\end{array}$ & $\begin{array}{l}56 \\
80\end{array}$ \\
\hline \multicolumn{9}{|l|}{ Auckland } \\
\hline $\begin{array}{l}<5 \\
<15\end{array}$ & $\begin{array}{l}40 \\
69\end{array}$ & $\begin{array}{l}45 \\
71\end{array}$ & $\begin{array}{l}36 \\
64 .\end{array}$ & $\begin{array}{l}43 \\
74\end{array}$ & $\begin{array}{l}35 \\
65\end{array}$ & $\begin{array}{l}15 \\
39\end{array}$ & $\begin{array}{l}31 \\
62\end{array}$ & $\begin{array}{l}48 \\
76\end{array}$ \\
\hline \multicolumn{9}{|l|}{ Montreal } \\
\hline $\begin{array}{l}<5 \\
<15\end{array}$ & $\begin{array}{l}30 \\
66\end{array}$ & $\begin{array}{l}35 \\
67\end{array}$ & $\begin{array}{l}24 \\
60\end{array}$ & $\begin{array}{l}29 \\
68\end{array}$ & $\begin{array}{l}31 \\
70\end{array}$ & $\begin{array}{l}18 \\
58\end{array}$ & $\begin{array}{l}27 \\
64\end{array}$ & $\begin{array}{l}44 \\
77\end{array}$ \\
\hline \multicolumn{9}{|l|}{ Baltimore } \\
\hline$<5$ & 31 & 37 & 24 & 33 & 27 & 9 & 29 & 50 \\
\hline$<15$ & 62 & 62 & 66 & 66 & 55 & 32 & 67 & 78 \\
\hline \multicolumn{9}{|l|}{ Umeå } \\
\hline$<5$ & 13 & 17 & 9 & 17 & 7 & 6 & 10 & 21 \\
\hline$<15$ & 45 & 47 & 45 & 45 & 43 & 44 & 42 & 52 \\
\hline
\end{tabular}

Table 6 Proportions walking to school and total streets crossed on foot by tertiles of school based response rate

\begin{tabular}{llll}
\hline Response tertile & Schools & $\begin{array}{l}\text { \% Walk to school } \\
(95 \% \text { CI })\end{array}$ & $\begin{array}{l}\text { Total streets crossed } \\
\text { (95\% CI) }\end{array}$ \\
\hline $\begin{array}{l}\text { Melbourne } \\
<78 \%\end{array}$ & 24 & $37(31$ to 43$)$ & $4.1(3.1$ to 5.1$)$ \\
$\begin{array}{l}78-90 \% \\
>90 \%\end{array}$ & 24 & $33(25$ to 40$)$ & $3.2(2.8$ to 3.6$)$ \\
$\begin{array}{l}\text { Montreal } \\
<51 \%\end{array}$ & 24 & $34(28$ to 40$)$ & $3.5(2.9$ to 4.0$)$ \\
$\begin{array}{l}<1-69 \% \\
>69 \%\end{array}$ & 14 & $46(28$ to 63$)$ & $5.4(4.1$ to 6.8$)$ \\
\hline
\end{tabular}

$\mathrm{CI}=$ confidence interval. to school, so that the low injury rates may have been achieved at the expense of activity levels This hypothesis was not supported by our data The proportion of children who walk to and from school in Umeå was similar to that ine Auckland. Moreover, children in Umeå cross nearly twice as many streets. Although thes degree to which children are accompanied mays have an important bearing on the injury ris/ per unit of exposure, these results do no? support the view that Sweden's low injury rates is because fewer children walk to or from school.

In all of the cities surveyed, children in families without a car were substantially more likely to walk to and from school and crossed greater number of streets, than children in car owning families. In Melbourne, children in families without a car crossed three times more streets than did children in two car families These gradients are likely to contribute to the steep social class gradients in child pedestriar? death rates. ${ }^{8}$

Some methodological limitations may have bearing on the results. Most important is the potential for bias due to non-response. Re $=$ sponse rates in Auckland, Melbourne, Perth and Montreal were reasonably high, but those in Umeå and Baltimore were low. If the travef patterns of non-respondents were substantially different to those of respondents, then nonf response may have biased the estimates ${ }_{\sigma}^{\omega}$ Although the effect of non-response is a matte for judgment, it may be appropriate to spec $\frac{-}{D}$ ulate as to the likely direction of any bias. Af? each site, including Umeå, children fromo families without a car were more likely to walle than children in car owning families. If if carp be assumed that socioeconomically disadvan $\frac{0}{2}$ taged families are over-represented among non-responders, then the effect of non-re sponse would be to underestimate the amoun of walking in Umeå. In this case, non-response bias, if present, would not affect our inter pretation of the results.

Alternatively, the impact of non-response can be judged by considering a worst case scenario. In Umeå, $41 \%$ of 9 years old bicycled from school. If it is assumed that none of the 
non-respondent 9 year olds in Umeå bicycled, then the prevalence of bicycling would be $18 \%$, still substantially greater than the other cities. Finally, our analyses of the proportions walking to school and the total streets crossed by tertiles of school based response rates did not show any clear relationship between pedestrian activity and response rates.

Because travel patterns were determined by self report, the validity of these data is open to question. The validity of interview reported pedestrian activity was studied by Routledge $e t$ al who observed a child's pedestrian activity one day and interviewed the same child the following day. ${ }^{9}$ The results showed that pedestrian exposure to risk was slightly underreported $-86 \%$ of the number of roads observed to be crossed were reported. Similar results were obtained in a validation study in Perth. ${ }^{10}$ Under-reporting of pedestrian activity is probably due to children forgetting road crossings. In our study, we attempted to minimise under-reporting by asking children to complete the questionnaire with their parents in the evening after systemically reviewing their road crossings for that day.

Through its effect on travel patterns, the urban transport infrastructure may influence both injury risk and levels of physical activity. World wide, traffic volume is predicted to increase well into the next century. ${ }^{11}$ This study provides a baseline against which future changes in childhood travel patterns can be judged. In cities everywhere, differential exposure to traffic is a major contributor to socioeconomic gradients in childhood mortality.

The study was funded by the following organisations: Federal Office of Road Safety (Melbourne), the Western Australian Health Promotion Foundation (Healthways) (Perth), Accident Rehabilitation and Compensation Insurance Corporation Rehabilitation and Compensation Insurance Corporation Program (Montreal), and the Swedish National Public Health Program (Montreal), and the Swedish National Public Health Institute and Swedish National Road Administration (Umeå). gratefully acknowledged.

1 Rivara FP. Child pedestrian injuries in the United States. $A m$ 7 Dis Child 1990; 144: 692-6.

2 Roberts I. The primary prevention of child pedestrian injuries. $B M$ F 1995; 310: 413-4.

3 Department of Health. The health of the nation: more people, more active, more often. London: Department of Health 1995.

4 Anonymous. Young and unfit [editorial]. Lancet 1992; 340: $19-20$.

5 Roberts I. International trends in pedestrian injury mortality. Arch Dis Child 1993; 68: 190-2.

6 Guyer B, Talbot AM, Pless IB. Pedestrian injuries to children and youth. Pediatr Clin North Am 1985; 31: children

7 Kish L. Survey sampling. New York: John Wiley and Sons, 1965.

8 Dougherty G, Pless IB, Wilkins R. Social class and the occurrence of traffic injuries and deaths in urban children. Can F Public Health 1990; 81: 204-9.

9 Routledge DA, Repetto-Wright R, Howarth CI. The comparison of interviews and observations to obtain measures of children's exposure to risk as pedestrians. Ergonomics 1974; 17: 623-38.

10 Stevenson MR. The validity of children's self reported exposure to traffic. Accid Anal Prev (in press)

11 Houghton J. Transport and the environment. (18th report.) London: HMSO, 1994. 